\title{
Prenatal testosterone exposure decreases colocalization of insulin receptors in kisspeptin/neurokinin B/dynorphin and agouti-related peptide neurons of the adult ewe
}

\author{
Maria Cernea, ${ }^{1,2}$ Rebecca Phillips, ${ }^{1,2}$ Vasantha Padmanabhan, ${ }^{3}$ Lique M. Coolen ${ }^{4}$ and Michael N. Lehman ${ }^{1}$ \\ ${ }^{1}$ Department of Neurobiology and Anatomical Sciences, The University of Mississippi Medical Center, Jackson, MS 39232, USA \\ ${ }^{2}$ Department of Anatomy \& Cell Biology, The University of Western Ontario, London, Canada \\ ${ }^{3}$ Department of Obstetrics and Gynecology, Pediatrics, and Reproductive Sciences Program, The University of Michigan, Ann \\ Arbor, MI, USA \\ ${ }^{4}$ Department of Physiology and Biophysics, The University of Mississippi Medical Center, Jackson, MS, USA
}

Keywords: agouti-related peptide, insulin receptor, kisspeptin, polycystic ovarian syndrome, sheep

Edited by Rae Silver

Received 6 January 2016, revised 26 July 2016, accepted 17 August 2016

\begin{abstract}
Insulin serves as a link between the metabolic and reproductive systems, communicating energy availability to the hypothalamus and enabling reproductive mechanisms. Adult Suffolk ewes prenatally exposed to testosterone (T) display an array of reproductive and metabolic dysfunctions similar to those seen in women with polycystic ovarian syndrome (PCOS), including insulin resistance. Moreover, prenatal T treatment alters neuropeptide expression in KNDy (co-expressing kisspeptin, neurokinin B/dynorphin) and agouti-related peptide (AgRP) neurons in the arcuate nucleus, two populations that play key roles in the control of reproduction and metabolism, respectively. In this study, we determined whether prenatal $\mathrm{T}$ treatment also altered insulin receptors in KNDy and AgRP neurons, as well as in preoptic area (POA) kisspeptin, pro-opiomelanocortin (POMC), and gonadotropin-releasing hormone $(\mathrm{GnRH})$ neurons of the adult sheep brain. Immunofluorescent detection of the beta subunit of insulin receptor (IR $\beta$ ) revealed that KNDy, AgRP and POMC neurons, but not GnRH or POA kisspeptin neurons, colocalize IR $\beta$ in control females. Moreover, prenatal $\mathrm{T}$ treatment decreased the percentage of KNDy and AgRP neurons that colocalized IR $\beta$, consistent with reduced insulin sensitivity. Administration of the anti-androgen drug, Flutamide, during prenatal $T$ treatment, prevented the reduction in IR $\beta$ colocalization in AgRP, but not in KNDy neurons, suggesting that these effects are programmed by androgenic and oestrogenic actions, respectively. These findings provide novel insight into the effects of prenatal $\mathrm{T}$ treatment on hypothalamic insulin sensitivity and raise the possibility that decreased insulin receptors, specifically within KNDy and AgRP neurons, may contribute to the PCOS-like phenotype of this animal model.
\end{abstract}

\section{Introduction}

Fertility is dependent on sufficient energy supply. Insulin is a key communicator of energy availability to the hypothalamus and specifically, gonadotropin-releasing hormone $(\mathrm{GnRH})$ neurons, enabling reproductive function in times of sufficient energy supply (Bruning et al., 2000). In women with polycystic ovary syndrome (PCOS), infertility and insulin resistance are a major concern and are exacerbated by excess weight (Franks, 1995; Holte, 1996; Dunaif, 1997; Steckler et al., 2009). Indeed, insulin resistance affects $50-70 \%$ of women with PCOS leading to a number of co-morbidities including metabolic syndrome, hypertension, dyslipidaemia, glucose intolerance and diabetes; while $40 \%$ of PCOS women are infertile (Sirmans \& Pate, 2014). The sheep model of PCOS, in which ewes are

Correspondence: Michael N. Lehman, as above.

E-mail: mlehman@umc.edu exposed to excess testosterone (T) during foetal life (from day 30 90 of gestation), is a well-characterized model that has been extensively utilized to understand and assess the molecular mediators involved in the reproductive and metabolic dysfunctions associated with this disorder (Dumesic et al., 2007). The prenatally androgenized sheep model mimics the reproductive and metabolic dysfunctions seen in women with PCOS (Padmanabhan et al., 2006; Dumesic et al., 2007; Abbott et al., 2008). The reproductive disruptions include polycystic ovaries (Padmanabhan \& Veiga-Lopez, 2011, 2013), intermittent to absent ovulation (Birch et al., 2003; Manikkam et al., 2006; Steckler et al., 2007; Veiga-Lopez et al., 2008), early reproductive failure (Clarke et al., 1977; Birch et al., 2003; Manikkam et al., 2006; Steckler et al., 2007; Veiga-Lopez et al., 2008), neuroendocrine feedback defects (Wood \& Foster, 1998; Robinson et al., 1999; Sharma et al., 2002; Sarma et al., 2005; Unsworth et al., 2005; Veiga-Lopez et al., 2009) and 
functional hyperandrogenism (Padmanabhan et al., 2010a). In addition, prenatal T-treated sheep are metabolically compromised and manifest reduced insulin sensitivity and compensatory hyperinsulinaemia (Recabarren et al., 2005; Padmanabhan et al., 2010b). Although the reproductive and metabolic outcomes of prenatal $\mathrm{T}$ exposure are well-described in the ewe, the mechanisms responsible for these detrimental effects, and the contribution of neural-level changes, are not well-understood.

In sheep and other mammals, the arcuate nucleus (ARC) of the hypothalamus is a major centre of convergence for reproductive and metabolic signals. This region contains two key populations of appetite regulating neurons, the orexigenic agouti-related peptide (AgRP) and the anorexigenic proopiomelanocortin (POMC) neurons, both of which have been shown to express insulin receptors (Morton \& Schwartz, 2001; Benoit et al., 2002). Previous work from our lab has shown that prenatal T-treated ewes show a more than twofold increase in the number of AgRP, but not POMC, neurons in the $\mathrm{ARC}$, as well as an increase in the density of AgRP fibre projections (Sheppard et al., 2011). In addition to the metabolic control neurons, the ARC also contains a key neuronal group involved in the control of GnRH secretion, the KNDy (co-expressing the neuropeptides kisspeptin, neurokinin $\mathrm{B}(\mathrm{NKB})$, dynorphin) neuronal population. Kisspeptin (located in both KNDy and preoptic neurons), NKB and dynorphin have each been proposed to serve distinct roles in modulating GnRH release depending on the steroid hormone milieu, mediating pulsatile and/or surge secretion of GnRH (de Roux et al., 2003; Seminara et al., 2003; Caraty et al., 2007; Dungan et al., 2007; Lehman et al., 2010; Smith et al., 2011). Previous work has found that prenatal T-treated females show a reduction in dynorphin and neurokinin B immunoreactivity in KNDy neurons, but no change in kisspeptin (Cheng et al., 2010). This peptide imbalance within the KNDy population has been postulated to contribute to the steroid feedback dysregulation and reproductive deficits seen in prenatal T-treated females. In addition to these findings, it has been shown that insulin sensitizer treatment improves reproductive function in prenatal T-treated females (Veiga-Lopez et al., 2010) and this is also seen in women with PCOS (Baillargeon et al., 2004; Legro et al., 2007), suggesting that insulin signalling is an important component of the PCOS phenotype, and may have impact on both metabolic and reproductive functions.

There is evidence from rodent studies that insulin can have significant effects on reproduction, acting at a neural level. For example, diabetic female rats show decreased luteinizing hormone (LH) surges and fewer ovulatory cycles (Steckler et al., 2009). Moreover, deletion of neuronal insulin receptors in mice affects metabolic and reproductive function. For example, Bruning et al., (2000) showed that mice with CNS-specific disruption of the IR gene displayed increased food intake, diet-sensitive obesity, mild insulin resistance and were sub-fertile. Moreover, Burks et al., (2000) showed that mice lacking insulin receptor substrate-2 (IRS-2), a component of the insulin/insulin-like growth factor-1 signalling cascade, had small, anovulatory ovaries with reduced numbers of follicles and were infertile. Importantly, restoration of insulin receptor expression in the brain is required to maintain fertility in these females (Okamoto et al., 2004). These actions may be mediated by direct insulin action on $\mathrm{GnRH}$ neurons or by afferent signals from other insulin sensitive neurons, including kisspeptin, AgRP or POMC neurons. There is evidence in rodents for insulin receptor expression in each of these populations (Morton \& Schwartz, 2001; Benoit et al., 2002), although selective deletion of the receptor in each population alone does not seem to compromise adult fertility at least in a major way (Könner et al., 2007; DiVall et al., 2010; Qiu et al., 2013). However, very little is known about the localization of insulin receptors in the sheep brain, and the possibility that prenatal $\mathrm{T}$ exposure alters its expression in specific neuronal subpopulations involved in reproduction and/or metabolic function has not been investigated.

Therefore, the goals of the present study were (i) to determine whether insulin receptors are present in kisspeptin and GnRH neurons in the adult sheep brain, and (ii) to examine the effect of prenatal $\mathrm{T}$ exposure on insulin receptor colocalization in these neuronal populations, as well as in AgRP and POMC neurons. Because insulin appears to play an important role in relaying energy availability to the reproductive axis, we predicted that prenatal T-treated ewes would show a decreased colocalization of insulin receptors in metabolic and reproductive neurons of the ewe, rendering these neurons less sensitive to insulin and thereby affecting processes that require specific information about energy availability. Finally, we asked whether such effects are due to androgenic or oestrogenic actions of prenatal $\mathrm{T}$ by examining colocalization of insulin receptors in animals in which the anti-androgen, Flutamide, was co-administered during prenatal $\mathrm{T}$ treatment.

\section{Materials and methods}

\section{Animals and experimental groups}

Suffolk ewes were cared for at the University of Michigan Sheep Research Facility (Ann Arbor, MI). Details of housing, nutrition, breeding, lambing and prenatal treatment have previously been described (Manikkam et al., 2004, 2006; Veiga-Lopez et al., 2008). Prenatal treatment involved administration of hormones to the pregnant mother between days 30 and 90 of gestation of a 147 day gestation period. The three experimental groups used in this study consist of adult female offspring treated prenatally with $\mathrm{T}$ ( $\mathrm{T}$ group; $n=5$ ), with $\mathrm{T}$ and Flutamide (TF; $n=5$ ), or Flutamide alone (F; $n=5$ ). Control females $(n=5)$ received an equal volume of vehicle $(2 \mathrm{~mL}$ cottonseed oil). If twin births occurred, only one offspring from the pair was included. All procedures conducted were approved by the Institutional Animal Care and Use Committee of the University of Michigan and were in accordance with the National Research Council's Guide for the Care and Use of Laboratory Animals.

T (T-propionate; Sigma-Alderich, St. Louis, MO) was injected i.m. twice weekly $(100 \mathrm{mg} / 2 \mathrm{~mL}$ dissolved in cottonseed oil; Sigma-Aldrich). Previous analysis of maternal and foetal blood circulation has demonstrated that this dosage of T produces levels similar to adult males and foetal males, respectively (Veiga-Lopez et al., 2011). Females in the $\mathrm{F}$ group received daily injections of Flutamide $(15 \mathrm{mg} / \mathrm{kg}$, Sigma-Alderich) dissolved in dimethylsulphoxide (400 mg/mL, Sigma-Aldrich) administered subcutaneously. Females in the TF group received T-propionate as described above in addition to daily injections of Flutamide.

\section{Tissue collection}

Brains were collected during the breeding season when females were 2 years of age. As in our previous studies (Sheppard et al., 2011), to normalize differences between prenatal T- treated and control ewes in endogenous steroid hormone levels present as a result of prenatal treatments, and any effect of these difference on insulin receptor or neuropeptide immunoreactivity, ewes were ovariectomized and implants used to normalize the endogenous hormonal milieu. Specifically, 3-4 weeks prior to tissue collection, animals were ovariectomized and were treated sequentially for 11-12 days with two controlled internal drug release $\mathrm{P}_{4}$ implants (CIDR; 
InterAG, Hamilton, Waikato, New Zealand) and then for 1 day with four 3-cm-long $E_{2}$ implants to simulate ovarian steroid levels during the late follicular phase of the cycle. Eighteen hours after the E2 implants, animals were killed. At time of tissue collection, all ewes received two intravenous injections (at $10 \mathrm{~min}$ intervals) of 25000 U heparin (catalogue \# 402588B; Abraxiz Pharmaceuticals, Schumberry, IL). Ewes were anaesthetized intravenously with sodium pentobarbital $(390 \mathrm{mg} / \mathrm{mL} / \mathrm{kg}$; Fatal Plus, Vortech, Dearborn, MI) and rapidly decapitated. The heads were immediately perfused through the internal carotid artery with $6 \mathrm{~L}$ of $4 \%$ paraformaldehyde (Sigma-Aldrich) dissolved in $0.1 \mathrm{~m}$ phosphate buffer (PB; SigmaAldrich) containing $0.1 \%$ sodium nitrate (Sigma-Aldrich), and $10 \mathrm{U} /$ $\mathrm{mL}$ heparin (Abraxiz Pharmaceuticals). Brains were submerged in the same fixative at $4{ }^{\circ} \mathrm{C}$ for $18 \mathrm{~h}$. Blocks of tissue containing hypothalami were transferred in $30 \%$ sucrose (Caledon, Georgetown, Ont., Canada) at $4{ }^{\circ} \mathrm{C}$ and sectioned coronally $(45 \mu \mathrm{m})$ using a freezing microtome (Microm, Walldorf, Germany) into 12 parallel series for each animal. Sectioned tissues were stored in cryoprotectant $(30 \%$ ethylene glycol, $0.1 \%$ sodium azide, $30 \%$ sucrose in $\mathrm{PB})$ at $-20{ }^{\circ} \mathrm{C}$ until further processing.

\section{Immunohistochemistry: general}

One series of every sixth section through the POA and hypothalamus from each animal were processed for immunohistochemistry. All incubations occurred at room temperature with gentle agitation. Free-floating sections were rinsed thoroughly with $0.1 \mathrm{M}$ phosphate-buffered saline (PBS) between incubations. Antibodies were dissolved in incubation solution consisting of $0.1 \mathrm{M}$ PBS, $0.4 \%$ Triton X-100 (catalogue item BP151-500; Sigma-Aldrich) containing 4\% normal goat serum (NGS; catalogue item 005-000-121; Jackson Immuno Research Laboratories, West Grove, PA). Unless otherwise specified, tissue sections were washed extensively with $0.1 \mathrm{M}$ PBS $(\mathrm{pH} 7.35)$ between steps. Prior to incubation with first primary antibody sections were incubated with $1 \%$ hydrogen peroxide $\left(10 \mathrm{~min}, \mathrm{H}_{2} \mathrm{O}_{2}\right.$; catalogue item H325; Fisher Scientific, Pittsburgh, PA) and incubation solution (1 h) to prevent non-specific background labelling. See Table S1 for detailed information on all primary antibodies used.

\section{Immunohistochemistry: triple-label immunofluorescence for AgRP/IR $\beta / P O M C$}

Sections were incubated overnight $(17 \mathrm{~h})$ with antibody specifically recognizing AgRP (raised in Guinea Pig, $1: 800$ dilution in incubation solution with 4\% NGS; Antibodies Australia, catalogue \# GPAAGRP.1, Lot \# AS506), and with goat anti-guinea pig Alexa 488 (1 : 100 dilution, 30 min, Molecular Probes, Inc., Carlsbad, CA). Next, sections were incubated overnight with antibody recognizing the beta sub-unit of the insulin receptor (IR $\beta$, raised in Rabbit, 1 : 300 dilution, Santa Cruz, C-19, SC-711), with biotinylated goat anti-rabbit $(1: 500$ dilution, $1 \mathrm{~h}$, Vector Laboratories, Burlingame, CA, USA), ABC-elite (1 : 500 dilution in PBS, $1 \mathrm{~h}$, Vector Laboratories), biotinylated tyramide (BT; $1: 250$ dilution in PBS with $1 \mu \mathrm{L}$ of $3 \% \mathrm{H}_{2} \mathrm{O}_{2} / \mathrm{mL}, 10 \mathrm{~min}$, Perkin Elmer Life Sciences, Woodbridge, Ont., Canada), and Alexa 555 conjugated streptavidin (1 : 100 dilution in PBS, 30 min, Molecular Probes). Finally, sections were incubated with antibody specifically recognizing POMC (raised in rabbit, 1:4000 in incubation solution with 4\% normal donkey serum, Phoenix Pharmaceuticals, Burlingame, CA, USA, catalogue \# H-029-30) and donkey anti-rabbit Cy5 (1 : 100 dilution in PBS, $30 \mathrm{~min}$, Molecular Probes). Sections were mounted on plus charged slides and cover slipped with gelvatol (Lennette, 1978).
Specificity of primary antibodies for POMC and AGRP has previously been demonstrated in sheep hypothalamic sections (Lennette, 1978). Pre-absorption of IR $\beta$ antibody with its corresponding peptide antigen (Santa Cruz) at concentration of $10 \mu \mathrm{g} / \mathrm{mL}$ for $24 \mathrm{~h}$ at $4{ }^{\circ} \mathrm{C}$ eliminated all immunoreactive staining (Fig. S1A, B). Finally, elimination of any single primary antibody while performing all other steps of the protocol eliminated all staining for the corresponding antigen and no others, demonstrating lack of cross-reactivity (Fig. S1C-H). The reason for lack of cross-reactivity for this protocol rests on the fact that the concentration of reagents used in detection of the first antigen are optimized such that they completely saturate available binding sites and there is no cross-reactivity with reagents used to detect the second antigen (Fig. S1F).

\section{Immunohistochemistry: dual-label immunofluorescence for kisspeptin/GnRH with IR $\beta$}

Sections were incubated overnight with antibody against $\operatorname{IR} \beta$, as described above. Next, sections were incubated overnight with antibody specifically recognizing kisspeptin (raised in rabbit, 1 : 200000 dilution, 17 h; kp10, lot 564; gift from Dr Alain Caraty, Nouzilly, France) or antibody specifically recognizing GnRH (raised in Mouse, $1: 400$ dilution, $17 \mathrm{~h}$, Sternberger Monoclonals, Inc., catalogue \#SMI-41R, Lot \#3). The next day, sections were washed and incubated with either goat anti-rabbit or goat anti-mouse Alexa 488 (1 : 100 dilution, $30 \mathrm{~min}$, Molecular Probes). Sections were mounted on plus charged slides and cover slipped with gelvatol (Lennette, 1978).

\section{Analysis}

We performed two independent analyses on these tissue sections. In the first analysis, we performed cell counts of the total number of AgRP, POMC, kisspeptin, and GnRH neurons in sections through the POA at the level of the organum vasculosum of the lamina terminalis (GnRH and kisspeptin, three sections/animal), the middle ARC at the level of the tuberoinfundibular sulcus (AgRP, POMC, and kisspeptin, five sections/animal), and the $\mathrm{MBH}$ at levels of the rostral to middle arcuate nucleus (GnRH, three sections/animal). Sections were examined at $20 \times$ magnification using Neurolucida software (MicroBrightfield Bioscience, Williston, VT, USA) and a digital camera (Microfire $\mathrm{A} / \mathrm{R}$, Optronics, CA, USA) attached to a fluorescent microscope (DM500B, Leica Microsystems, Wetzlar, Germany). We calculated the mean number \pm SEM for each region as appropriate (e.g., GnRH cells in the POA and MBH, kisspeptin cells in the POA and ARC).

In the second analysis, we used confocal microscopy to examine AGRP, POMC, kisspeptin, and GnRH neurons for colocalization with IR $\beta$. Specifically, we used a Zeiss LSM-510 laser-scanning confocal microscope system (Zeiss, Heidelberg, Germany), to capture images of the $\mathrm{ARC}, \mathrm{POA}$ and $\mathrm{MBH}$ in Z-stacks comprised of $1 \mu \mathrm{m}$ optical sections. Alexa 555 fluorescence (IR $\beta$ ) was imaged with a HeNe1 laser and a $543 \mathrm{~nm}$ emission filter. Alexa 488 fluorescence (kisspeptin, GnRH or AgRP) was imaged with an Argon laser and a $488 \mathrm{~nm}$ emission filter. Cy5 fluorescence (POMC) was imaged with a $\mathrm{HeNe} 2$ laser and a $633 \mathrm{~nm}$ emission filter. For each cell type in the ARC (AgRP, POMC, kisspeptin), between 39 and 44 neurons per animal were examined in serial $1 \mu \mathrm{m}$ optical sections throughout their entire extent. For GnRH and POA kisspeptin neurons, every cell identified in the captured $\mathrm{Z}$ stacks was analysed for colocalization with IR $\beta$. Percentages of the kisspeptin (ARC and POA), GnRH, AgRP and POMC-ir neurons that colocalized IR $\beta$-ir were calculated per animal, and the mean percentage \pm SEM was 
determined for each group. Differences between groups, for both total cell counts and percentage colocalization, were determined using Two Way Analysis of Variance, and Tukey's Multiple Comparison Test for post hoc comparisons. For pairwise comparisons between treatment groups, Dunn's Method or Fisher LSD Method post hoc tests were performed. 95\% confidence levels were applied to all tests. In addition, for comparison of the magnitude of treatment effects on total cell counts, we also performed effect size analysis (Cohen, 1992; Nakagawa \& Cuthill, 2007; Padmanabhan et al., 2015). This analysis allows comparison of the means between treatments with respect to the magnitude of difference between them. The computed statistic is Cohen's $d$ value, and values above 0.2 , 0.5 , and 0.8 were considered as small, medium and large effect sizes, respectively (Cohen, 1992; Nakagawa \& Cuthill, 2007).

\section{Results}

\section{Colocalization of IR $\beta$ with AgRP, POMC and arcuate kisspeptin neurons in control ewes}

In the ARC of control ewes, the vast majority of AgRP (85\%) and POMC (92\%) cell bodies colocalized IR $\beta$ (Fig. 1, top panel; also see Fig. S2). Similarly, 94\% of ARC kisspeptin (KNDy) neurons colocalized IR $\beta$ (Fig. 2, top panel). By contrast, we observed no instances of colocalization among the 104 preoptic area (POA) kisspeptin neurons examined in five control animals (Fig. 3). Similarly, while IR $\beta$-immunoreactive neurons were present in areas of the POA and MBH where GnRH neurons were located, of over 300 GnRH neurons examined in five control animals, none colocalized IR $\beta$ (Fig. 4). Despite the lack of colocalization of IR $\beta$ in POA kisspeptin or GnRH cell bodies, we observed numerous instances of IR $\beta$-positive axonal boutons that were in direct contact with POA kisspeptin (Fig. 3) and GnRH (Fig. 4) somas. IR $\beta$-positive boutons were also seen in direct contact with ARC kisspeptin neurons (e.g., Fig. 2, bottom panel). We observed no obvious regional differences in the distribution of colocalized cells, or in the location of IR $\beta$ positive axon terminals, within the POA or ARC of control ewes.

\section{Effects of prenatal T treatment on total number of AgRP, POMC and arcuate kisspeptin neurons, and their colocalization with IR $\beta$}

Prenatal $\mathrm{T}$ treatment had no effect on either the number of POMC $\left(F_{3,18}: 3.16, P=0.833\right)$ or arcuate kisspeptin (KNDy) neurons (Fig. $5 ; F_{3,16}: 3.24, P=0.141$ ). Although there was a trend towards increased numbers of AgRP neurons in prenatal T animals compared to control ewes, this difference did not reach significance $\left(F_{3,19}\right.$ : 2.65, $P=0.077$ ). Analysis of effect size showed a large effect of prenatal $\mathrm{T}$ on the total numbers of AgRP neurons $(d=1.373)$ but not on POMC $(d=0.062)$ or KNDy $(d=0.289)$ cells. Co-treatment with the anti-androgen, Flutamide, did not significantly alter the number of AgRP, POMC or KNDy neurons compared to those numbers seen in control ewes (Fig. 5; $P=0.077, P=0.833$, and $P=0.141$, respectively). Although AgRP and KNDy neuron numbers tended to be higher and lower, respectively, in ewes receiving anti-androgen treatment alone, these differences did not reach statistical significance $\left(F_{3,19}: 2.65, P=0.077 ; F_{3,16}: 2.11, P=0.141\right)$.

Our analysis of a similar-sized subsets of AgRP, POMC and KNDy neurons revealed that prenatal $T$ treatment significantly decreased the percentage of IR $\beta$ colocalization within AgRP neurons (Fig. 6, top; $F_{3,22}: 4.35, P=0.003$ ), but not within POMC neurons (Fig. 6, middle). Co-treatment with the anti-androgen, Flutamide, blocked this effect of prenatal $\mathrm{T}$, with prenatal TF-treated females showing a similar percentage of IR $\beta$ colocalization with AgRP neurons as controls ( $85 \%$ vs. $83 \%)$ and a significantly greater percentage of colocalization than prenatal $\mathrm{T}$ females $(83 \%$ vs. $73 \%$, $P<0.05)$. Anti-androgen treatment alone had no effect on the percentage of IR $\beta$ colocalization in either AgRP or POMC neurons, relative to controls (Fig. 6, top and middle panels; $85 \%$ vs. $83 \%$ and $92 \%$ vs. $94 \%$, respectively, ns).
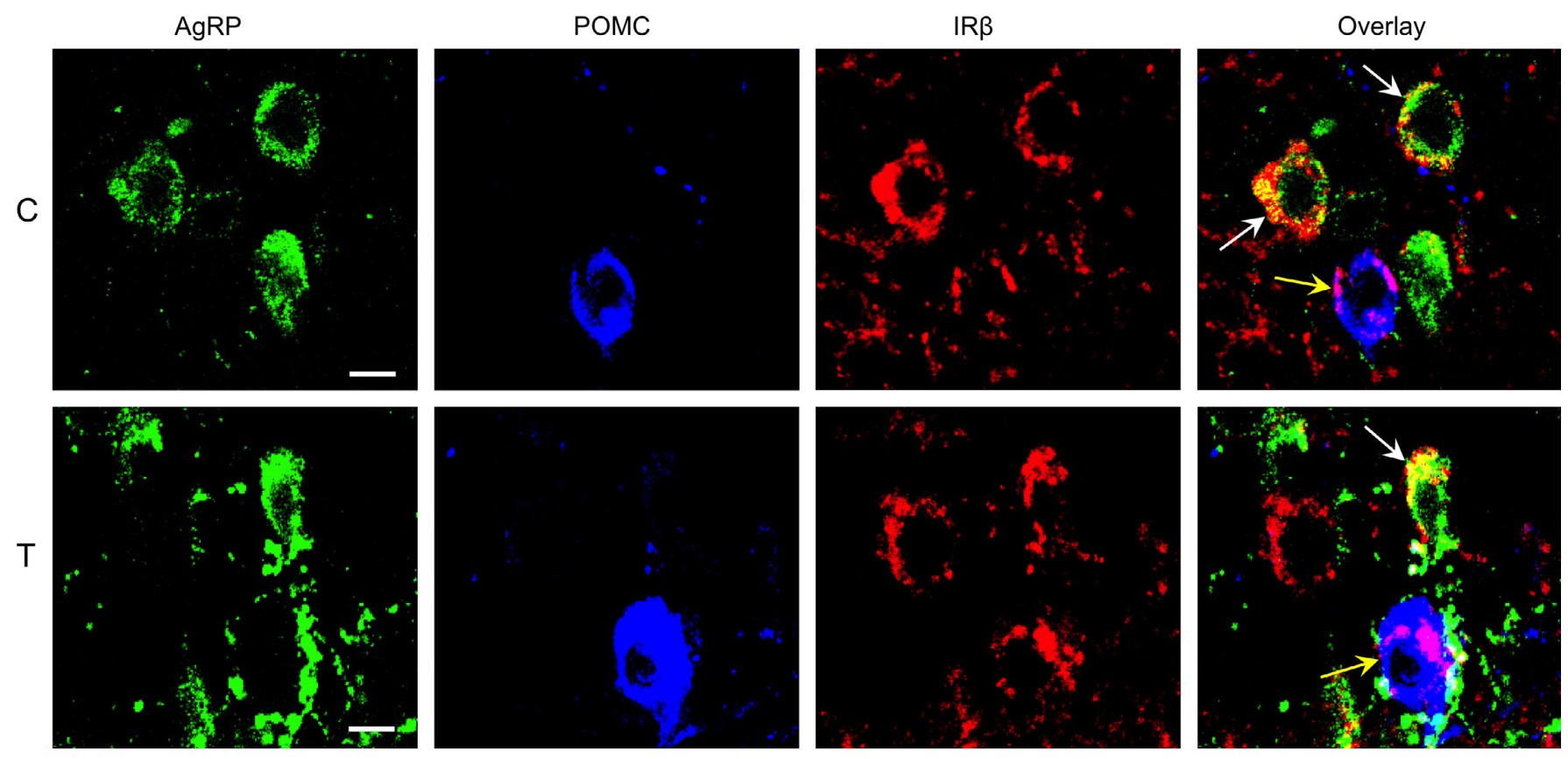

FIG. 1. Confocal images of triple-labeled $1 \mu \mathrm{m}$ optical sections showing examples of AgRP-(green), POMC-(blue), and IR $\beta$-immunolabelled neurons (red) in the arcuate nucleus of control $(\mathrm{C}$, top panel) and prenatal $\mathrm{T}$ ( $\mathrm{T}$, bottom panel) ewes. Overlay images (far right panels) show colocalization of IR $\beta$ with AgRP (white arrows) and POMC (yellow arrows) neurons. Scale bars $=10 \mu \mathrm{m}$. 

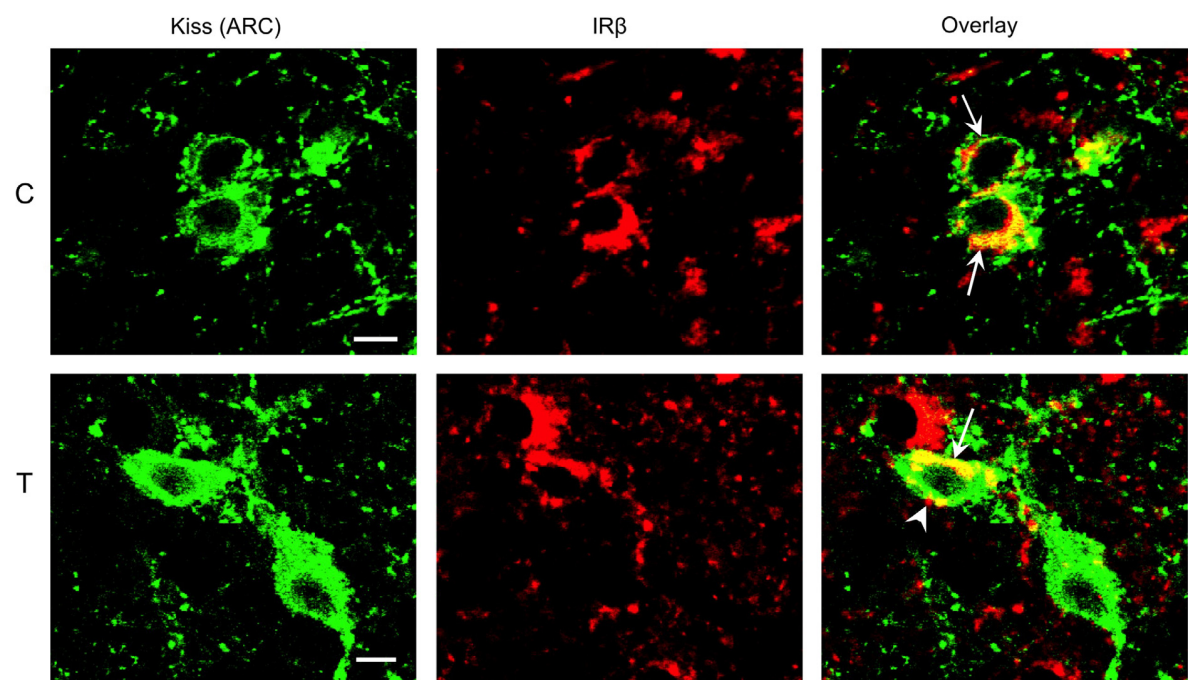

FIG. 2. Confocal images of dual-labelled $1 \mu \mathrm{m}$ optical sections showing kisspeptin-(green) and IR $\beta$-immunoreactive (red) neurons and fibres in the arcuate nucleus (ARC) of control (C, top panel) and prenatal T (T, bottom panel) ewes. Examples of dual-labelled kisspeptin/IR $\beta$ neurons (arrows) are indicated in the overlay images. In addition, an IR $\beta$-positive terminal bouton (arrowhead) is seen in direct contact with a kisspeptin cell body in the lower panel. Scale bars $=10 \mu \mathrm{m}$.
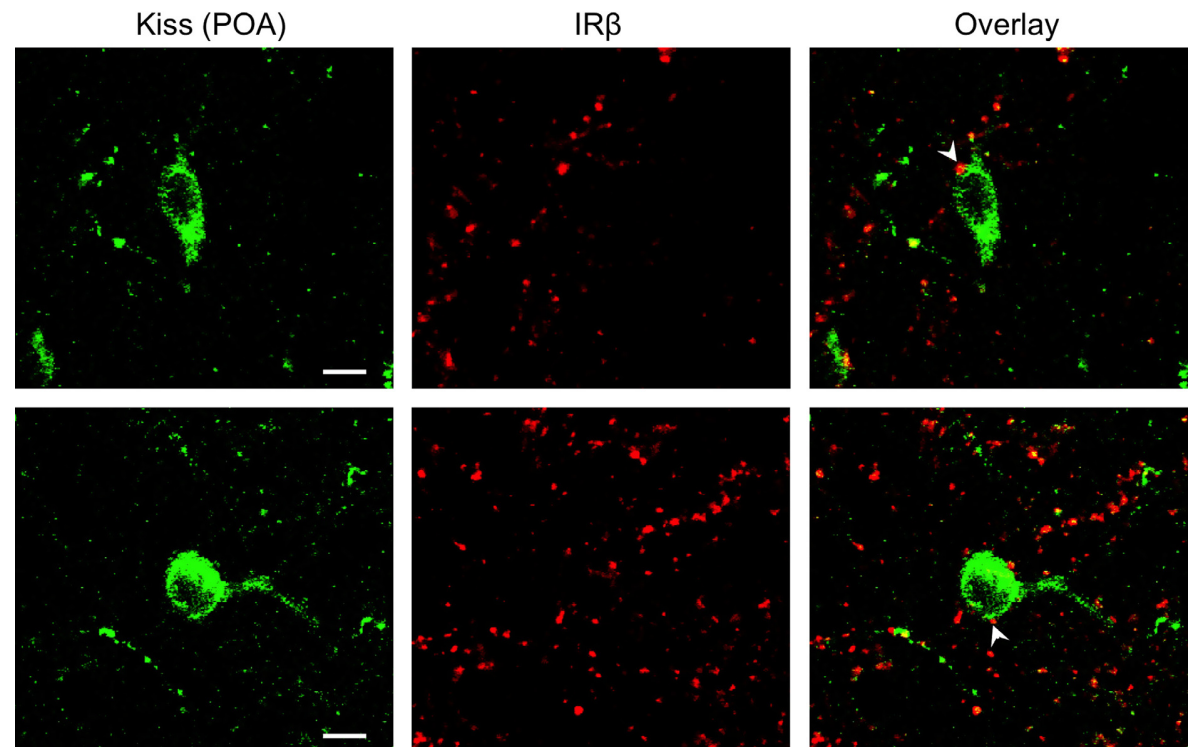

FIG. 3. Confocal images showing the absence of IR $\beta$ (red) colocalization in kisspeptin neurons (green) of the preoptic area (POA) in control ewes. Despite the lack of cellular colocalization, IR $\beta$-positive boutons were frequently seen in association with kisspeptin cell bodies (e.g., arrowheads). Scale bars $=10 \mu \mathrm{m}$.

Similar to the effects seen in AgRP neurons, prenatal T treatment significantly decreased the percentage of IR $\beta$ colocalization in ARC kisspeptin neurons $\left(F_{3,19}\right.$ : 9.07, $P=0.001$; Fig. 6 , bottom). Unlike the effects of prenatal T on IR $\beta / \operatorname{AgRP}$ colocalization, co-treatment with anti-androgen did not reverse the decrease in the percentage of IR $\beta$ colocalization within ARC kisspeptin neurons in prenatal $\mathrm{T}$ ewes (Fig. 6, bottom panel; 73\% vs. 76\%; ns). Females treated prenatally with anti-androgen alone showed a similar percentage of IR $\beta /$ kisspeptin colocalization as control females ( $94 \%$ vs. $91 \%$, ns).

\section{Discussion}

This study is the first to provide evidence of changes in brain insulin receptors in the prenatally androgenized sheep model of PCOS (Dumesic et al., 2007). Since one of the hallmarks of this model is insulin resistance (Padmanabhan et al., 2010b), changes in insulin receptor at the level of the hypothalamus, and within identified neuron groups important for metabolism (AgRP) and reproduction (KNDy), may play a key role in long-term changes in insulin sensitivity observed in these animals. In our previous study (Sheppard et al., 2011), we found that prenatal $\mathrm{T}$ treatment increased the number of AgRP neurons, but not POMC neurons, in the middle portion of the ARC. In the current study, the difference between control and prenatal $\mathrm{T}$ animals in number of AgRP cells failed to reach significance, although effect size analysis confirmed a large difference between control and prenatal $\mathrm{T}$ animals in the number of AgRP but not POMC neurons. In light of this, for the co-localization analysis, we examined a similar sample size of neurons across groups. We demonstrated that prenatal $\mathrm{T}$ treatment decreased the percentage of colocalization of IR $\beta$ in AgRP, but not in POMC neurons, suggesting that these changes are specific to the AgRP population. Since AgRP expression is inhibited by insulin (Qu et al., 2001; Breen 

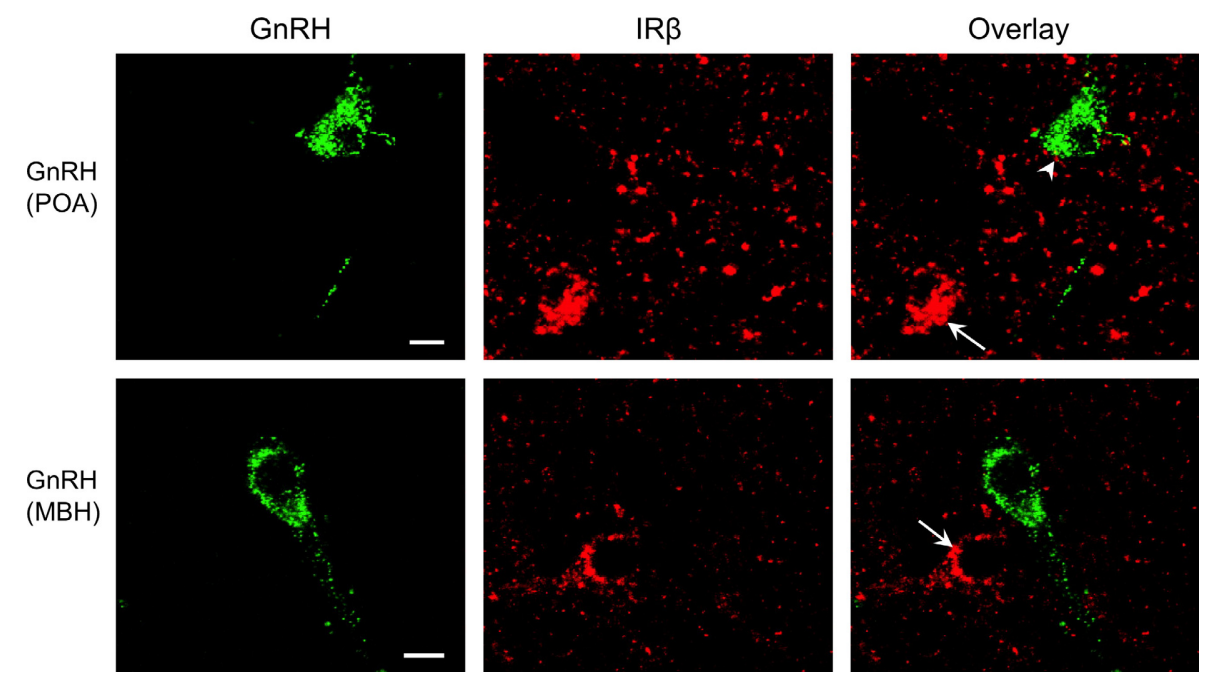

FIG. 4. Confocal images showing examples of GnRH neurons in the POA (top panel) and the mediobasal hypothalamus (MBH, bottom panel) of control ewes, and the absence of IR $\beta$ (red) colocalization with these neurons despite the presence of adjacent IR $\beta$-positive neurons (arrows). Arrowhead indicates an example of an IR $\beta$-positive bouton in contact with a POA GnRH neuron. Scale bar $=10 \mu \mathrm{m}$.

et al., 2005), decreased colocalization of insulin receptors in AgRP but not POMC neurons could potentially provide an explanation for the increase in AgRP but not POMC peptide suggested by our previous work (Sheppard et al., 2011). Finally, we found that co-treatment with the androgen antagonist, Flutamide, blocked the effects of prenatal T on IR $\beta$ colocalization within AgRP, but not KNDy neurons, indicating that the changes in these two populations may be organized by different actions of prenatal $\mathrm{T}$, androgenic and oestrogenic, respectively.

\section{Effects of prenatal $T$ treatment on IR $\beta$ colocalization in AgRP and POMC neurons}

Prenatal T treatment significantly decreased the percentage of AgRP, but not POMC, neurons colocalizing IR $\beta$ in the ARC compared with controls. The AgRP-specific decrease in IR $\beta$ is consistent with our previous results showing increased numbers of AgRP-ir neurons, but not POMC-ir neurons in prenatal T-treated females (Sheppard et al., 2011). As noted above, since insulin decreases AgRP mRNA levels (Qu et al., 2001) and peptide release (Breen et al., 2005) in normal females, the decreased IR $\beta$ colocalization within AgRP neurons may be partly responsible for the increased AgRP cell number seen in prenatal $\mathrm{T}$ females (Sheppard et al., 2011). In turn, both reduced IR $\beta$ colocalization in AgRP neurons, and increased AgRP peptide expression, may be contributing factors to the metabolic and reproductive deficits seen in these animals. Previous studies have found that prenatal T-treated females are insulin resistant and develop compensatory hyperinsulinaemia as adults (Recabarren et al., 2005; Padmanabhan et al., 2010b). However, in the present study, we did not correlate metabolic defects with the observed neuroanatomical changes, and evidence for correlations between dysregulated insulin signalling and receptor colocalization in the same cohort should be explored as a next step. In addition, neither POMC or AgRP-specific IR knockout mice show major defects in body weight or fertility, although control of hepatic glucose production is impaired in these mice (Könner et al., 2007). Nevertheless, the changes observed in our study represent only a portion of the disruptions caused by prenatal $\mathrm{T}$ exposure, and therefore, when combined with additional alterations may result in a more severe phenotype than previously reported. Although IR in AgRP neurons are not essential for adult fertility (Könner et al., 2007), this neuronal subpopulation may still play an important role relaying the influence of metabolic cues to the reproductive neuroendocrine system. AgRP neurons project directly to GnRH neurons in the rat (Li et al., 1999) and inhibit reproduction by suppressing pulsatile LH release in the rhesus monkey (Vulliémoz et al., 2005). Similarly, neuropeptide Y (NPY), an orexigenic neuropeptide, which is largely colocalized with AgRP (Hahn et al., 1998; Sheppard et al., 2011), inhibits reproduction by hindering GnRH neuronal firing in mice (Sullivan \& Moenter, 2004; Klenke et al., 2010) and tonic secretion of LH in the sheep (McShane et al., 1993; Adam et al., 1997). We do not know whether NPY peptide, like AgRP, is increased in prenatal T sheep, but it is conceivable that increased AgRP and/or NPY peptide and its release may be a means by which this population could inhibit $\mathrm{GnRH}$ release in prenatal T-exposed females, and contribute to some of the observed defects including a decrease in the magnitude of the LH surge (see below).

Prenatal TF treatment successfully rescued the effects of T on IR $\beta$ colocalization with AgRP neurons, suggesting that the decrease in $\operatorname{IR} \beta$ in this subpopulation is prenatally organized by the androgenic actions of $\mathrm{T}$. These effects of $\mathrm{T}$ parallel organizational effects of prenatal T on AgRP expression (Sheppard et al., 2011), albeit more completely. We previously showed that co-treatment of $\mathrm{T}$ with androgen antagonist (TF) was able to largely, but not completely, rescue the effects of prenatal T on AgRP neuron numbers (Sheppard et al., 2011). Moreover, the effects of prenatal $\mathrm{T}$ on insulin resistance and AgRP neuron numbers are mimicked by prenatal dihydrotestosterone (DHT, a non-aromatizable androgen) treatment (Padmanabhan et al., 2010b; Sheppard et al., 2011), further implicating an androgenic programming role of $\mathrm{T}$ in this population. However, prenatal $\mathrm{T}$-induced hyperinsulinaemia and insulin resistance were not reversed by Flutamide co-treatment (TF) in a recent study (Table 1; Cardoso et al., 2016), suggesting that the change in IR colocalization in AGRP neurons is not sufficient by itself to account for the metabolic alterations seen in this model. A caveat to this conclusion is that the metabolic changes in aforementioned study (Cardoso et al., 2016) were observed in juvenile animals; hence the decreased IR $\beta$ colocalization in AgRP neurons may still be a contributing factor for hyperinsulinaemia and insulin resistance in adult prenatal $\mathrm{T}$ ewes. 

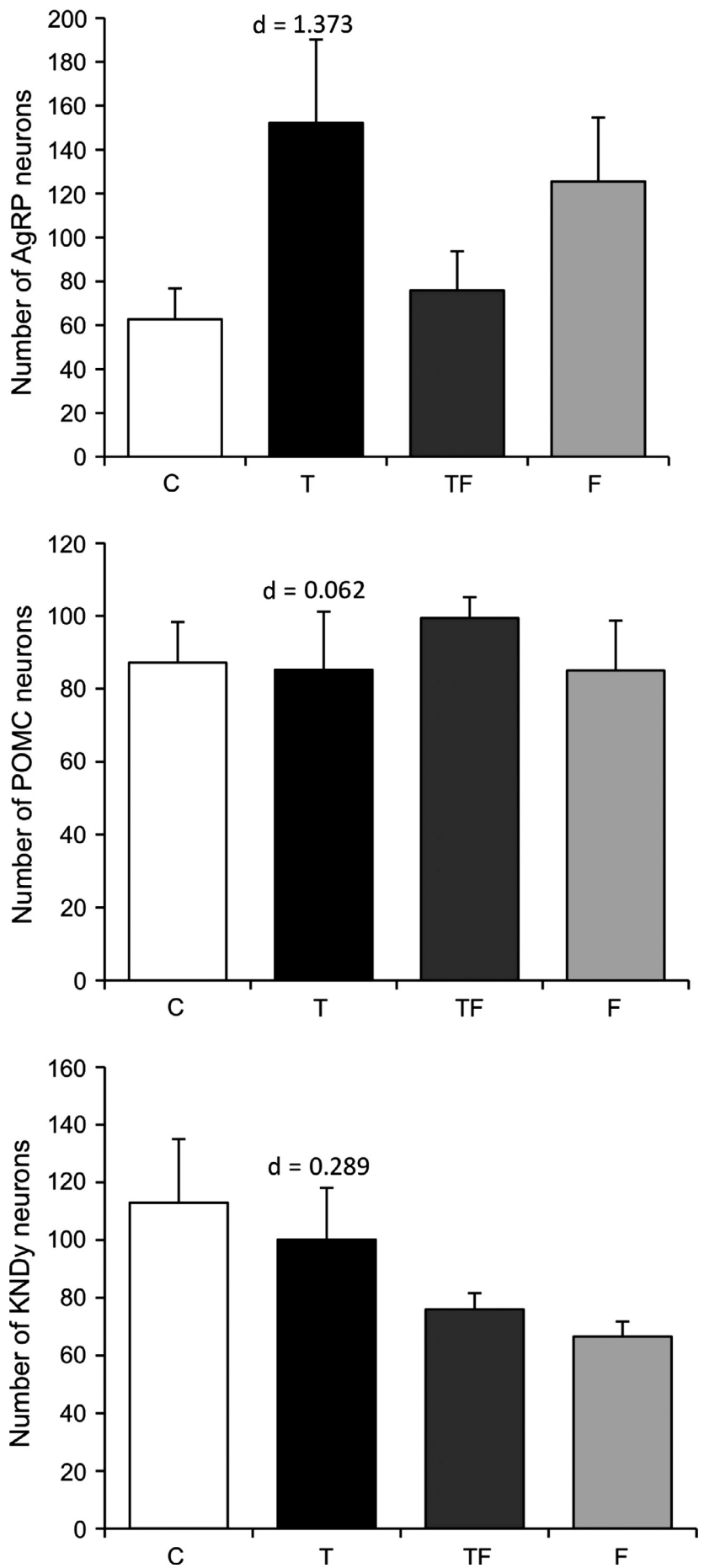

FIG. 5. Mean \pm SEM total number of AgRP (top), POMC (middle), and kisspeptin (KNDy, bottom) neurons in the arcuate nucleus of control $(n=5)$, prenatal $\mathrm{T}(n=5)$, prenatal TF $(n=5)$, and prenatal $\mathrm{F}(n=5)$ ewes. Although the total numbers of cells did not differ significantly across groups, size effect analysis (Cohen's $d$ value) indicates a large difference between control and $\mathrm{T}$ groups in number of AgRP but not POMC or KNDy cells.

\section{Effects of prenatal T treatment of IR $\beta$ colocalization in ARC kisspeptin (KNDy) neurons}

We found that approximately $94 \%$ of KNDy neurons colocalize IR $\beta$ and that prenatal $\mathrm{T}$ treatment results in a significant decrease in IR $\beta$ colocalization in these neurons. Reproductive deficits in prenatal Ttreated females include increased LH pulsatility and a delayed and
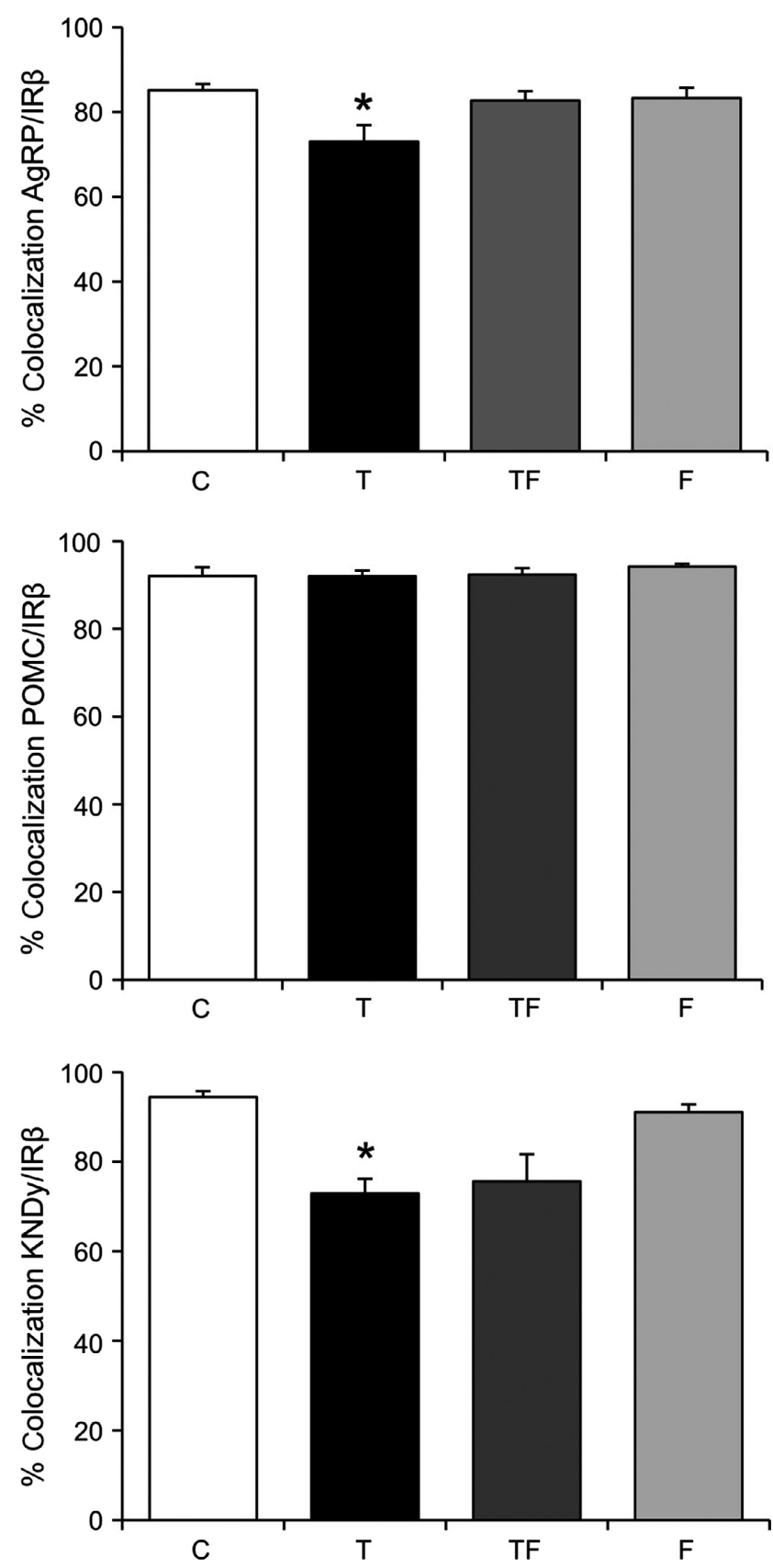

FIG. 6. Mean \pm SEM percentage colocalization of AgRP (top), POMC (middle), and kisspeptin (KNDy, bottom) neurons with IR $\beta$ in the arcuate nucleus of control $(n=5)$, prenatal $\mathrm{T}(n=5)$, prenatal TF $(n=5)$, and prenatal $\mathrm{F}(n=5)$ ewes. *Indicates significant difference $(P<0.05)$ from controls.

dampened LH surge culminating in ablation of ovulatory cycles (Robinson et al., 1999; Sharma et al., 2002; Sarma et al., 2005; Unsworth et al., 2005; Veiga-Lopez et al., 2009). As noted earlier, postnatal insulin sensitizer treatment improves reproductive function in prenatal T-treated females (Veiga-Lopez et al., 2010). Moreover, insulin has been shown to stimulate GnRH and LH secretion in vivo (Moret et al., 2009) and in vitro (Burcelin et al., 2003), an effect which is mediated at the level of the hypothalamus and not the pituitary. However, because GnRH neurons in sheep do not appear to contain IR $\beta$, the influence of insulin upon the reproductive axis in this species is likely relayed to GnRH neurons via afferent neurons expressing this receptor. 
TABLE 1. Summary of results from prior studies on the ability of prenatal co-treatment with anti-androgen (Flutamide) to reverse metabolic and reproductive defects produced by prenatal testosterone $(\mathrm{T})$ treatment

\begin{tabular}{|c|c|c|}
\hline $\begin{array}{l}\text { Defect/changes produced } \\
\text { by prenatal } \mathrm{T} \text { treatment }\end{array}$ & $\begin{array}{l}\text { Reversal by } \\
\text { Flutamide } \\
\text { co-treatment } \\
\text { (TF)? }\end{array}$ & Reference \\
\hline \multicolumn{3}{|l|}{ Metabolic } \\
\hline Hyperinsulinaemia (juvenile) & No & Cardoso et al. (2016) \\
\hline Insulin resistance (juvenile) & No & \\
\hline \multicolumn{3}{|l|}{ Reproductive } \\
\hline Decreased LH surge amplitude & $\mathrm{No} / \mathrm{Yes}$ & Abi-Salloum \\
\hline Delayed LH surge timing & No & $\begin{array}{l}\text { et al. (2012), } \\
\text { Padmanabhan } \\
\text { et al. (2015) }\end{array}$ \\
\hline Advanced puberty & Yes & $\begin{array}{l}\text { Jackson } \\
\text { et al. (2008), } \\
\text { Padmanabhan } \\
\text { et al. }(2015)\end{array}$ \\
\hline
\end{tabular}

KNDy neurons represent one such potential relay. KNDy neurons have been strongly implicated in the control of pulsatile GnRH secretion (Wakabayashi et al., 2010; Okamura et al., 2013) and, in sheep, also appear to be activated during the preovulatory $\mathrm{GnRH}$ surge (Merkley et al., 2012). A role for insulin in facilitation of the GnRH/LH surge has been described (Bruning et al., 2000; Steckler et al., 2009; Veiga-Lopez et al., 2010) and recent work in prenatal T-treated sheep showed that postnatal insulin sensitizer treatment increased the magnitude of the LH surge (Abi-Salloum et al., 2012). Furthermore, ovine KNDy neurons are activated by leptin treatment (Backholer et al., 2010) albeit indirectly (Louis et al., 2011), and colocalize IR $\beta$ (this study) rendering this subpopulation responsive to metabolic signals (Fu \& van den Pol, 2010). Finally, there is an array of substantial evidence in rodents that KNDy neurons play an important role in mediating metabolic control of reproduction (Castellano et al., 2005, 2006, 2009, 2010; Pinilla et al., 2012). However, recent studies of female mice with kisspeptin-specific deletion of phospholipid enzyme phosphoinositide 3-kinase (PI3K), a major signalling target for insulin, show that normal pubertal development, LH levels, and oestrous cyclicity is unaffected in these animals (Beymer et al., 2012) suggesting that insulin signalling via kisspeptin neurons (including KNDy neurons) may not be essential by itself for female adult reproductive function. In addition, mice with insulin receptors conditionally deleted from either GABA-, glutamate- or CamKII alpha-expressing neurons are completely fertile (Evans et al., 2014b). Thus, the influence of insulin upon GnRH secretion is most probably not conveyed by any single neuronal population, and likely requires a larger aggregate of neurons and their projections that collectively funnel this input to the GnRH neurosecretory unit. In the sheep, KNDy neurons may participate in conveying the influence of insulin upon GnRH secretion in concert with other neurons, since they have direct contacts with AgRP and POMC neurons (Backholer et al., 2010), and, in turn, both AgRP/NPY and POMC neurons send projections that synapse on GnRH neurons (Norgren \& Lehman, 1989; Jansen et al., 2003). Finally, it should be noted that insulin can act at either hypothalamic, pituitary, or ovarian levels to regulate follicular development (Adashi et al., 1981; Poretsky \& Kalin, 1987). Thus, alterations in IR $\beta$ expression in KNDy neurons, together with changes in receptor expression in other neurons and/or levels of the reproductive axis, may ultimately contribute to the defects in reproductive function seen in this model.
In contrast with IR $\beta$ colocalization in AgRP neurons, co-treatment with androgen antagonist did not rescue the effects of prenatal $\mathrm{T}$ on $\operatorname{IR} \beta$ colocalization in KNDy neurons, suggesting that the decrease in $\operatorname{IR} \beta$ in this subpopulation is organized by the oestrogenic actions of T. It is unlikely that the inability of anti-androgen (Flutamide) cotreatment to reverse this effect was due to an insufficient dose since the same co-treatment was able to completely reverse the decrease in IR/AgRP colocalization. Moreover, this dose has been previously shown to block the effect of prenatal $\mathrm{T}$ on AgRP neuron number (Sheppard et al., 2011) and reverse the external masculinization seen in this model (Jackson et al., 2008). An alternate possibility is that the changes in IR $\beta$ in KNDy neurons are programmed by androgenic effects of $\mathrm{T}$ via other intermediaries, for example those leading to an increase in gestational insulin levels (Abi-Salloum et al., 2012). However, recent findings that prenatal co-treatment with insulin sensitizer fails to rescue the effects of prenatal $\mathrm{T}$ treatment on GnRH/LH surge (Abi-Salloum et al., 2012) argue against this possibility. Nonetheless, increased insulin levels during the period of foetal exposure to excess $\mathrm{T}$, when insulin levels in the mother are also increased (Abi-Salloum et al., 2012), might intensify the degree of disturbance in this model.

Previous studies of the ability of anti-androgen co-treatment to ameliorate reproductive defects produced by prenatal $\mathrm{T}$ treatment have suggested that some but not all of these defects are due to androgenic actions (Table 1). Specifically, previous results showed that Flutamide co-treatment reversed the advanced puberty seen in prenatal $\mathrm{T}$ ewes (Jackson et al., 2008; Padmanabhan et al., 2015) but not the delayed timing of the LH surge (Abi-Salloum et al., 2012; Padmanabhan et al., 2015). Data regarding the ability of androgen antagonist co-treatment to reverse decreased peak amplitude of the surge is equivocal with an earlier study testing positive feedback in ovary-intact animals showing increased magnitude of the LH surge in prenatal $\mathrm{T}$ ewes receiving Flutamide co-treatment (Abi-Salloum et al., 2012) but a more recent study characterizing hormonal dynamics during natural follicular phase finding no effect of prenatal androgen antagonist treatment on LH surge amplitude in prenatal T sheep (Padmanabhan et al., 2015). Preliminary data from the current cohort of animals studied during the artificial follicular phase is similar to the positive feedback results (Abi-Salloum et al., 2012), with prenatal T ewes showing a significant decrease in peak LH surge amplitude compared to controls that is reversed in the TF group (unpublished observations). Thus, the decreased IR $\beta$ colocalization in KNDy neurons seen in prenatal $\mathrm{T}$ ewes is unlikely by itself to be responsible for the decreased LH surge amplitude, although it could still contribute to this defect.

\section{Absence of IR $\beta$ localization in GnRH neurons and POA kisspeptin neurons in the ewe}

In contrast with AgRP, POMC and KNDy neurons, we found no evidence of colocalization of IR $\beta$ in either GnRH neurons or POA kisspeptin neurons of the brains of control ewes. The absence of IR $\beta$ colocalization with GnRH neurons suggests that metabolic signals controlling reproductive status in sheep are relayed via an upstream population of neurons. Although insulin receptors have been previously detected in immortalized GnRH cell lines (Kim et al., 2005) and insulin receptor mRNA and protein have been recently shown in GnRH neurons in mice (Evans et al., 2014a), insulin-induced phospho-Akt or phospho-extracellular-signal-regulated kinase (pERK) 1/2 was not observed in these GnRH neurons (Evans et al., 2014a), suggesting that insulin may exert its effects 
via upstream neuronal populations. In addition, only 5\% (Evans et al., 2014a) to $22 \%$ (Qiu, 2013) of murine kisspeptin neurons colocalize IR $\beta$, compared to $94 \%$ of ARC kisspeptin neurons in the sheep, suggesting that the mechanism of insulin action in the sheep brain, and particularly its effects on GnRH, differs from that in the mouse. As noted above, KNDy neurons as well as AgRP neurons represent possible candidates for conveying insulin signals to $\mathrm{GnRH}$ neurons, since both populations of neurons colocalize IR $\beta$, have direct projections to GnRH neurons (Li et al., 1999; Lehman et al., 2010; Roa \& Herbison, 2012), and have been shown to regulate GnRH activity (Sullivan \& Moenter, 2004; Vulliémoz et al., 2005; Caraty et al., 2007; Klenke et al., 2010; Lehman et al., 2010). While we found no colocalization of IR $\beta$ in POA kisspeptin neurons, the possibility remains that this subset of kisspeptin neurons may participate in these actions via inputs from other insulin-sensitive neurons. Finally, although recent work suggests that insulin receptors in KNDy and POA kisspeptin neurons in mice may not be essential for adult reproduction (Qiu et al., 2013), these neurons may play redundant roles with other populations, including AgRP neurons, in this function.

\section{IR $\beta$ localization in axon terminals: an additional site of insulin action on the reproductive neuroendocrine system?}

In addition to IR $\beta$ colocalization in arcuate neurons (KNDy, AgRP and POMC), we also observed frequent instances of IR $\beta$ positive boutons that were in direct contact with kisspeptin neurons in both the ARC (Fig. 2) and POA (Fig. 3), as well as in contact with GnRH cell bodies (Fig. 4). Earlier studies in rodents have shown insulin receptors, detected by IR $\beta$ immunoreactivity, are present in synapses of cultured hippocampal neurons (Abbott et al., 1999) as well as in axon terminal regions of the hippocampal formation (Park et al., 2009), and that insulin can act presynaptically to induce phosphorylation of insulin receptor substrate-1 and Akt (Heras-Sandoval et al., 2012). More relevant to the current findings is older work showing that insulin binding sites in the rat are present within the external zone of the median eminence (van Houten et al., 1980) and that these binding sites are dependent on projections arising from the ARC (van Houten et al., 1983). While we did not specifically examine the sheep median eminence for IR $\beta$ immunoreactivity, KNDy neurons project to the median eminence where they may modulate GnRH secretion via synapses onto GnRH dendrons (Iremonger \& Herbison, 2015) and axo-axonic contacts with GnRH terminals (Lehman et al., 2013). Therefore, we would speculate that contacts between IR $\beta$-containing axon terminals and kisspeptin or GnRH neurons may represent an additional presynaptic site of action for the effects of insulin on control of GnRH secretion. While confirmation of the IR $\beta$-positive close contacts we observed as bona fide synapses awaits co-localization with markers such as synaptophysin (Cernea et al., 2015), their appearance as strings of beaded varicosities (e.g., Fig. 3, middle panel) are consistent with that of peptidergic axons and suggest that at least some of the boutons are presynaptic in nature.

\section{Conclusions}

A summary of our current findings of changes in insulin receptors and metabolic peptides as a consequence of prenatal exposure to $\mathrm{T}$ in female sheep, and their relationship with the reproductive neuroendocrine system, is shown in Fig. 7. KNDy neurons have been posited as a major intermediary, conveying metabolic signals to

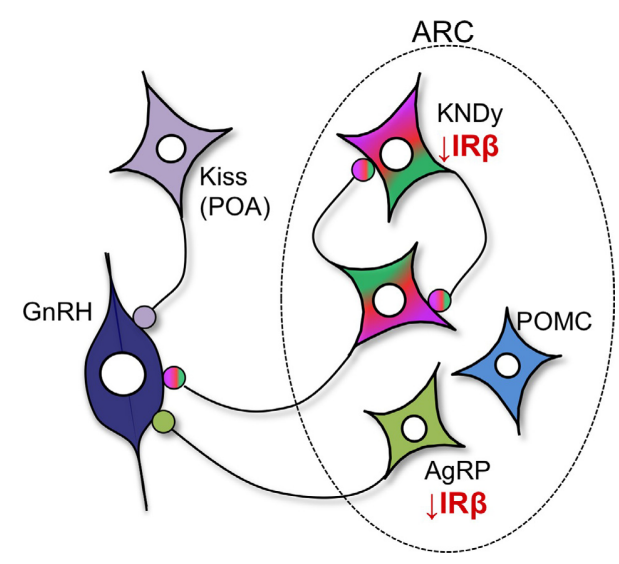

FIG. 7. Schematic diagram illustrating the long-term consequences of prenatal $\mathrm{T}$ treatment on insulin receptor beta (IR $\beta$ ) colocalization within AgRP, POMC and KNDy neurons in the female sheep hypothalamus. Decreased IR $\beta$ in AgRP neurons may, in part, underlie the increase in AgRP peptide previously observed in prenatal T ewes (Sheppard et al., 2011). Moreover, decreased IR $\beta$ colocalization within AgRP and KNDy neurons may result in decreased insulin sensitivity in these neurons and altered steroid feedback control of GnRH secretion, thereby contributing to the metabolic and reproductive disruptions seen in the PCOS-like phenotype of this animal model.

GnRH neurons (Castellano et al., 2005, 2006, 2009, 2010; Pinilla et al., 2012); although direct projections of AgRP and POMC neurons to GnRH neurons are also present (Leranth et al., 1988; Li et al., 1999; Rondini et al., 2004; Roa \& Herbison, 2012). KNDy neurons form a reciprocally interconnected neuronal population whose activity is hypothesized to play a key role in regulating $\mathrm{GnRH}$ pulsatile secretion, as well as participate in the control of the GnRH surge in sheep and primates (Lehman et al., 2010). Prenatal $\mathrm{T}$ exposure leads to decreased IR $\beta$ in KNDy neurons, and also decreased expression of two of the three KNDy peptides, neurokinin $\mathrm{B}$ and dynorphin (not shown). In addition, prenatal $\mathrm{T}$ exposure results in decreased in IR $\beta$ in AgRP but not POMC neurons, and our previous findings suggest a corresponding increase in AgRP but not POMC peptide in these populations. The precise functional impact of each of these changes on the control of GnRH secretion in the adult, specifically with respect to the defects in steroid feedback responsiveness seen in this animal model (Robinson et al., 1999; Sharma et al., 2002; Sarma et al., 2005; Unsworth et al., 2005; Veiga-Lopez et al., 2009), remains to be determined; however, a first step will be to determine whether pre- or postnatal treatments with insulin sensitizers, such as Rosiglitazone, can reverse any of these receptor/peptide changes. Ultimately, the challenge will be to understand the early developmental cascade of events initiated by exposure to excess $T$ that result in adult reproductive and metabolic dysfunction, and to determine which of the long-term hypothalamic alterations seen in the adult offspring may contribute to functional deficits. Our results reveal the programming effects of prenatal $\mathrm{T}$ on insulin receptor levels in identified, subsets of neurons in the sheep brain, and raises the possibility that decreased insulin receptors, specifically within KNDy and AgRP neurons, may contribute in part to the metabolic disruptions seen in the PCOS-like phenotype of this animal model.

\section{Conflicts of interest}

The authors have no conflicts of interest to declare. 


\section{Supporting Information}

Additional supporting information can be found in the online version of this article:

Table S1. Primary antibody information.

Fig. S1. IR $\beta$ antibody controls.

Fig. S2. Triple-label detection of AgRP, POMC and IR $\beta$.

\section{Acknowledgements}

We thank Mr Douglas Doop for assistance with breedinglambing, his expert and conscientious animal care, and Sheep Facility management. This research was supported by NIH P01 HD044232 to V.P., M.N.L., and L.C.

\section{References}

Abbott, D.H., Bruns, C.M., Barnett, D.K., Tarantal, A.F., Hoffmann, S.M., Zhou, R., Levine, J.E. \& Dumesic, D.A. (2008) Fetal origins of the polycystic ovarian syndrome. In Dunaif, A., Chang, R.J., Franks, S. \& Legro, R.S. (Eds), Polycystic Ovarian Syndrome, 1st Edn. Humana Press, Totowa, NJ, pp. 87-106.

Abbott, M.A., Wells, D.G. \& Fallon, J.R. (1999) The insulin receptor tyrosine kinase substrate $\mathrm{p} 58 / 53$ and the insulin receptor are components of CNS synapses. J. Neurosci., 19, 7300-7308.

Abi-Salloum, B., Herkimer, C., Lee, J.S., Veiga-Lopez, A. \& Padmanabhan, V. (2012) Developmental programming: prenatal and postnatal contribution of androgens and insulin in the reprogramming of estradiol positive feedback disruptions in prenatal testosterone-treated sheep. Endocrinology, 153, 2813-2822.

Adam, C.L., Findlay, P.A., Kyle, C.E., Young, P. \& Mercer, J.G. (1997) Effect of chronic food restriction on pulsatile luteinizing hormone secretion and hypothalamic neuropeptide Y gene expression in castrate male sheep. J. Endocrinol., 152, 329-337.

Adashi, E.Y., Hsueh, A.J. \& Yen, S.S. (1981) Insulin enhancement of luteinizing hormone and follicle-stimulating hormone release by cultured pituitary cells. Endocrinology, 108, 1441-1449.

Backholer, K., Smith, J.T., Rao, A., Pereira, A., Iqbal, J., Ogawa, S., Li, Q. \& Clarke, I.J. (2010) Kisspeptin cells in the ewe brain respond to leptin and communicate with neuropeptide $\mathrm{Y}$ and proopiomelanocortin cells. Endocrinology, 151, 2233-2243.

Baillargeon, J.P., Jakubowicz, D.J., Iuorno, M.J., Jakubowicz, S. \& Nestler, J.E. (2004) Effects of metformin and rosiglitazone, alone and in combination, in nonobese women with polycystic ovary syndrome and normal indices of insulin sensitivity. Fertil. Steril., 82, 893-902.

Benoit, S.C., Air, E.L., Coolen, L.M., Strauss, R., Jackman, A., Clegg, D.J., Seeley, R.J. \& Woods, S.C. (2002) The catabolic action of insulin in the brain is mediated by melanocortins. J. Neurosci., 22, 9048-9052.

Beymer, M., Aziz, R., Mayer, C., Fukuda, M., Lin, R.Z., Boehm, U. \& Acosta-Martinez, M. (2012) The effects of a Kisspeptin-cell specific deletion of PI3K catalytic subunits $\mathrm{p} 110 \alpha$ and $\mathrm{p} 110 \beta$ on the hypothalamicpituitary-gonadal axis. Endocr. Rev., 33, SUN-701.

Birch, R.A., Padmanabhan, V., Foster, D.L., Unsworth, W.P. \& Robinson, J.E. (2003) Prenatal programming of reproductive neuroendocrine function: fetal androgen exposure produces progressive disruption of reproductive cycles in sheep. Endocrinology, 144, 1426-1434.

Breen, T.L., Conwell, I.M. \& Wardlaw, S.L. (2005) Effects of fasting, leptin, and insulin on AGRP and POMC peptide release in the hypothalamus. Brain Res., 1032, 141-148.

Bruning, J.C., Gautam, D., Burks, D.J., Gillette, J., Schubert, M., Orban, P.C., Klein, R., Krone, W. et al. (2000) Role of brain insulin receptor in control of body weight and reproduction. Science, 289, 2122-2125.

Burcelin, R., Thorens, B., Glauser, M., Gaillard, R.C. \& Pralong, F.P. (2003) Gonadotropin-releasing hormone secretion from hypothalamic neurons: stimulation by insulin and potentiation by leptin. Endocrinology, 144, 4484-4491.

Burks, D.J., de Mora, J.F., Schubert, M., Withers, D.J., Myers, M.G., Towery, H.H., Altamuro, S.L., Flint, C.L. et al. (2000) IRS-2 pathways integrate female reproduction and energy homeostasis. Nature, 407, 377-382.

Caraty, A., Smith, J.T., Lomet, D., Ben Said, S., Morrissey, A., Cognie, J., Doughton, B., Baril, G. et al. (2007) Kisspeptin synchronizes preovulatory surges in cyclical ewes and causes ovulation in seasonally acyclic ewes. Endocrinology, 148, 5258-5267.
Cardoso, R.C., Veiga-Lopez, A., Moeller, J., Beckett, E., Pease, A., Keller, E., Madrigal, V., Chazenbalk, G. et al. (2016) Developmental programming: impact of gestational steroid and metabolic milieus on adiposity and insulin sensitivity in prenatal testosterone-treated female sheep. Endocrinology, 157, 522-535.

Castellano, J.M., Navarro, V.M., Fernandez-Fernandez, R., Nogueiras, R., Tovar, S., Roa, J., Vazquez, M.J., Vigo, E. et al. (2005) Changes in hypothalamic KiSS-1 system and restoration of pubertal activation of the reproductive axis by kisspeptin in undernutrition. Endocrinology, 146, 3917-3925.

Castellano, J.M., Navarro, V.M., Fernández-Fernández, R., Roa, J., Vigo, E., Pineda, R., Dieguez, C., Aguilar, E. et al. (2006) Expression of hypothalamic KiSS-1 system and rescue of defective gonadotropic responses by kisspeptin in streptozotocin-induced diabetic male rats. Diabetes, 55, 26022610.

Castellano, J.M., Navarro, V.M., Roa, J., Pineda, R., Sanchez-Garrido, M.A., Garcia-Galiano, D., Vigo, E., Dieguez, C. et al. (2009) Alterations in hypothalamic KiSS-1 system in experimental diabetes: early changes and functional consequences. Endocrinology, 150, 784-794.

Castellano, J.M., Bentsen, A.H., Mikkelsen, J.D. \& Tena-Sempere, M. (2010) Kisspeptins: Bridging energy homeostasis and reproduction. Brain Res., 1364, 129-138.

Cernea, M., Padmanabhan, V., Goodman, R.L., Coolen, L.M. \& Lehman, M.N. (2015) Prenatal testosterone treatment leads to changes in the morphology of KNDy neurons, their inputs, and projections to GnRH cells in female sheep. Endocrinology, 156, 3277-3291.

Cheng, G., Coolen, L.M., Padmanabhan, V., Goodman, R.L. \& Lehman, M.N. (2010) The kisspeptin/neurokinin B/dynorphin (KNDy) cell population of the arcuate nucleus: sex differences and effects of prenatal testosterone in sheep. Endocrinology, 151, 301-311.

Clarke, I.J., Scaramuzzi, R.J. \& Short, R.V. (1977) Ovulation in prenatally androgenized ewes. J. Endocrinol., 73, 385-389.

Cohen, J. (1992) A power primer. Psychol. Bull., 112, 155-159.

DiVall, S.A., Williams, T.R., Carver, S.E., Koch, L., Bruning, J.C., Kahn, C.R., Wondisford, F., Radovick, S. et al. (2010) Divergent roles of growth factors in the GnRH regulation of puberty in mice. J. Clin. Invest., 120, 2900-2909.

Dumesic, D.A., Abbott, D.H. \& Padmanabhan, V. (2007) Polycystic ovary syndrome and its developmental origins. Rev. Endocr. Metab. Dis., 8, 127141.

Dunaif, A. (1997) Insulin resistance and the polycystic ovary syndrome: mechanism and implications for pathogenesis. Endocr. Rev., 18, 774-800.

Dungan, H.M., Gottsch, M.L., Zeng, H., Gragerov, A., Bergmann, J.E., Vassilatis, D.K., Clifton, D.K. \& Steiner, R.A. (2007) The role of kisspeptinGPR54 signaling in the tonic regulation and surge release of gonadotropin-releasing hormone/luteinizing hormone. J. Neurosci., 27, 1208812095.

Evans, M.C., Rizwan, M., Mayer, C., Boehm, U. \& Anderson, G.M. (2014a) Evidence that insulin signalling in gonadotrophin-releasing hormone and kisspeptin neurones does not play an essential role in metabolic regulation of fertility in mice. J. Neuroendocrinol., 26, 468-479.

Evans, M.C., Rizwan, M.Z. \& Anderson, G.M. (2014b) Insulin action on GABA neurons is a critical regulator of energy balance but not fertility in mice. Endocrinology, 155, 4368-4379.

Franks, S. (1995) Polycystic ovary syndrome. New Engl. J. Med., 333, 853861.

Fu, L.Y. \& van den Pol, A.N. (2010) Kisspeptin directly excites anorexigenic proopiomelanocortin neurons but inhibits orexigenic neuropeptide Y cells by an indirect synaptic mechanism. J. Neurosci., 30, 1020510219.

Hahn, T.M., Breininger, J.F., Baskin, D.G. \& Schwartz, M.W. (1998) Coexpression of Agrp and NPY in fasting-activated hypothalamic neurons. Nat. Neurosci., 1, 271-272.

Heras-Sandoval, D., Ferrera, P. \& Arias, C. (2012) Amyloid- $\beta$ protein modulates insulin signaling in presynaptic terminals. Neurochem. Res., 37, $1879-1885$.

Holte, J. (1996) Disturbances in insulin secretion and sensitivity in women with the polycystic ovary syndrome. Bailliere. Clin. Endoc., 10, 221247.

Houten, M., Posner, B.I., Kopriwa, B.M. \& Brawer, J.R. (1980) Insulin binding sites localized to nerve terminals in rat median eminence and arcuate nucleus. Science, 207, 1081.

Iremonger, K.J. \& Herbison, A.E. (2015) Multitasking in gonadotropinreleasing hormone neuron dendrites. Neuroendocrinology, 102, 1-7. 
Jackson, L.M., Timmer, K.M. \& Foster, D.L. (2008) Sexual differentiation of the external genitalia and the timing of puberty in the presence of an antiandrogen in sheep. Endocrinology, 149, 4200-4208.

Jansen, H.T., Cutter, C., Hardy, S., Lehman, M.N. \& Goodman, R.L. (2003) Seasonal plasticity within the GnRH system of the ewe: changes in identified $\mathrm{GnRH}$ inputs and in glial association. Endocrinology, 144, 3663-3676.

Kim, H.H., DiVall, S.A., Deneau, R.M. \& Wolfe, A. (2005) Insulin regulation of GnRH gene expression through MAP kinase signaling pathways. Mol. Cell. Endocrinol., 242, 42-49.

Klenke, U., Constantin, S. \& Wray, S. (2010) Neuropeptide Y directly inhibits neuronal activity in a subpopulation of gonadotropin-releasing hormone-1 neurons viaY1receptors. Endocrinology, 151, 2736-2746.

Könner, A.C., Janoschek, R., Plum, L., Jordan, S.D., Rother, E., Ma, X., Xu, C., Enriori, P. et al. (2007) Insulin action in AgRP-expressing neurons is required for suppression of hepatic glucose production. Cell Metab., 5, 438-449.

Legro, R.S., Zaino, R.J., Demers, L.M., Kunselman, A.R., Gnatuk, C.L., Williams, N.I. \& Dodson, W.C. (2007) The effects of metformin and rosiglitazone, alone and in combination, on the ovary and endometrium in polycystic ovary syndrome. Am. J. Obstet. Gynecol., 196, 402.

Lehman, M.N., Coolen, L.M. \& Goodman, R.L. (2010) Minireview: kisspeptin/neurokinin B/dynorphin (KNDy) cells of the arcuate nucleus: a central node in the control of gonadotropin-releasing hormone secretion. Endocrinology, 151, 3479-3489.

Lehman, M.N., Hileman, S.M. \& Goodman, R.L. (2013) Neuroanatomy of the kisspeptin signaling system in mammals: comparative and developmental aspects. In Kauffman, A. \& Smith, J. (Eds), Chapter 3 in Kisspeptin Signaling in Reproductive Biology. Advances in Experimental Medicine and Biology, vol 784. Springer-Verlag, New York, pp. 27-62.

Lennette, D.A. (1978) An improved mounting medium for immunofluorescence microscopy. Am. J. Clin. Pathol., 69, 647-648.

Leranth, C., MacLusky, N.J., Shanabrough, M. \& Naftolin, F. (1988) Immunohistochemical evidence for synaptic connections between pro-opiomelanocortinimmunoreactive axons and LH-RH neurons in the preoptic area of the rat. Brain Res., 449, 167-176.

Li, C., Chen, P. \& Smith, M.S. (1999) Morphological evidence for direct interaction between arcuate nucleus neuropeptide Y (NPY) neurons and gonadotropin-releasing hormone neurons and the possible involvement of NPY Y1 receptors. Endocrinology, 140, 5382-5390.

Louis, G.W., Greenwald-Yarnell, M., Phillips, R., Coolen, L.M., Lehman, M.N. \& Myers, M.G. (2011) Molecular mapping of the neural pathways linking leptin to the neuroendocrine reproductive axis. Endocrinology, 152, 2302-2310

Manikkam, M., Crespi, E.J., Doop, D.D., Herkimer, C., Lee, J.S., Yu, S., Brown, M.B., Foster, D.L. et al. (2004) Fetal programming: prenatal testosterone excess leads to fetal growth retardation and postnatal catch-up growth in sheep. Endocrinology, 145, 790-798.

Manikkam, M., Steckler, T.L., Welch, K.B., Inskeep, E.K. \& Padmanabhan, V. (2006) Fetal programming: prenatal testosterone treatment leads to follicular persistence/luteal defects; partial restoration of ovarian function by cyclic progesterone treatment. Endocrinology, 147, 1997-2007.

McShane, T.M., Petersen, S.L., McCrone, S. \& Keisler, D.H. (1993) Influence of food restriction on neuropeptide-Y, proopiomelanocortin, and luteinizing hormone-releasing hormone gene expression in sheep hypothalami. Biol. Reprod., 49, 831-839.

Merkley, C.M., Porter, K.L., Coolen, L.M., Hileman, S.M., Billings, H.J., Drews, S., Goodman, R.L. \& Lehman, M.N. (2012) KNDy (Kisspeptin/ Neurokinin B/Dynorphin) neurons are activated during both pulsatile and surge secretion of LH in the ewe. Endocrinology, 153, 5406-5414.

Moret, M., Stettler, R., Rodieux, F., Gaillard, R.C., Waeber, G., Wirthner, D., Giusti, V., Tappy, L. et al. (2009) Insulin modulation of luteinizing hormone secretion in normal female volunteers and lean polycystic ovary syndrome patients. Neuroendocrinology, 89, 131-139.

Morton, G.J. \& Schwartz, M.W. (2001) The NPY/AgRP neuron and energy homeostasis. Int. J. Obes. Relat. Metab. Disord., 25, S56-S62.

Nakagawa, S. \& Cuthill, I.C. (2007) Effect size, confidence interval and statistical significance: a practical guide for biologists. Biol. Rev. Camb. Philos., 82, 591-605.

Norgren, R.B. Jr \& Lehman, M.N. (1989) A double label pre-embedding immunoperoxidase technique for electron microscopy using diaminobenzidine and tetramethylbenzidine as markers. J. Histochem. and Cytochem., 37, 1283-1289.

Okamoto, H., Nakae, J., Kitamura, T., Park, B.-C., Dragatsis, I. \& Accili, D. (2004) Transgenic rescue of insulin receptor-deficient mice. J. Clin. Invest., 114, 214-223.
Okamura, H., Tsukamura, H., Ohkura, S., Uenoyama, Y., Wakabayashi, Y. \& Maeda, K. (2013) Kisspeptin and GnRH pulse generation. Adv. Exp. Med. Biol., 784, 297-323.

Padmanabhan, V. \& Veiga-Lopez, A. (2011) Developmental origin of reproductive and metabolic dysfunctions: androgenic versus estrogenic reprogramming. Semin. Reprod. Med., 29, 173-186.

Padmanabhan, V. \& Veiga-Lopez, A. (2013) Sheep models of polycystic ovary syndrome phenotype. Mol. Cell. Endocrinol., 373, 8-20.

Padmanabhan, V., Manikkam, M., Recabarren, S. \& Foster, D. (2006) Prenatal testosterone excess programs reproductive and metabolic dysfunction in the female. Mol. Cell. Endocrinol., 246, 165-174.

Padmanabhan, V., Sarma, H.N., Savabieasfahani, M., Steckler, T.L. \& VeigaLopez, A. (2010a) Developmental reprogramming of reproductive and metabolic dysfunction in sheep: native steroids vs. environmental steroid receptor modulators. Int. J. Androl., 33, 394-404.

Padmanabhan, V., Veiga-Lopez, A., Abbott, D.H., Recabarren, S.E. \& Herkimer, C. (2010b) Developmental programming: impact of prenatal testosterone excess and postnatal weight gain on insulin sensitivity index and transfer of traits to offspring of overweight females. Endocrinology, 151, 595-605.

Padmanabhan, V., Veiga-Lopez, A., Herkimer, C., Salloum, B.A., Moeller, J., Beckett, E. \& Sreedharan, R. (2015) Developmental programming: prenatal and postnatal androgen antagonist and insulin sensitizer interventions prevent advancement of puberty and improve LH surge dynamics in prenatal testosterone-treated sheep. Endocrinology, 156, 2678-2692.

Park, C.W., Yoo, K.-Y., Hwang, I.K., Choi, J.H., Lee, C.H., Park, O.K., Cho, J.H., Lee, Y.L. et al. (2009) Age-related changes in the insulin receptor $\beta$ in the gerbil hippocampus. Neurochem. Res., 34, 2154-2162.

Pinilla, L., Aguilar, E., Dieguez, C., Millar, R.P. \& Tena-Sempere, M. (2012) Kisspeptins and reproduction: physiological roles and regulatory mechanisms. Physiol. Rev., 92, 1235-1316.

Poretsky, L. \& Kalin, M.F. (1987) The gonadotropic function of insulin. Endocr. Rev., 8, 132-141.

Qiu, X., Dowling, A.R., Marino, J.S., Faulkner, L.D., Bryant, B., Brüning, J.C., Elias, C.F. \& Hill, J.W. (2013) Delayed puberty but normal fertility in mice with selective deletion of insulin receptors from Kiss1 cells. Endocrinology, 154, 1337-1348.

Qu, S.Y., Yang, Y.K., Li, J.Y., Zeng, Q. \& Gantz, I. (2001) Agouti-related protein is a mediator of diabetic hyperphagia. Regul. Peptides, 98, 6975.

Recabarren, S.E., Padmanabhan, V., Codner, E., Lobos, A., Durán, C., Vidal, M., Foster, D.L. \& Sir-Petermann, T. (2005) Postnatal developmental consequences of altered insulin sensitivity in female sheep treated prenatally with testosterone. Am. J. Physiol-Endoc. M., 289, E801-E806.

Roa, J. \& Herbison, A.E. (2012) Direct regulation of GnRH neuron excitability by arcuate nucleus POMC and NPY neuron neuropeptides in female mice. Endocrinology, 153, 5587-5599.

Robinson, J.E., Forsdike, R.A. \& Taylor, J.A. (1999) In utero exposure of female lambs to testosterone reduces the sensitivity of the gonadotropinreleasing hormone neuronal network to inhibition by progesterone. Endocrinology, 140, 5797-5805.

Rondini, T.A., Baddini, S.P., Sousa, L.F., Bittencourt, J.C. \& Elias, C.F. (2004) Hypothalamic cocaine- and amphetamine-regulated transcript neurons project to areas expressing gonadotropin releasing hormone immunoreactivity and to the anteroventral periventricular nucleus in male and female rats. Neuroscience, 125, 735-748.

de Roux, N., Genin, E., Carel, J.C., Matsuda, F., Chaussain, J.L. \& Milgrom, E. (2003) Hypogonadotropic hypogonadism due to loss of function of the KiSS1-derived peptide receptor GPR54. Proc. Natl. Acad. Sci. USA, 100, 10972-10976.

Sarma, H.N., Manikkam, M., Herkimer, C., Dell'Orco, J., Welch, K.B., Foster, D.L. \& Padmanabhan, V. (2005) Fetal programming: excess prenatal testosterone reduces postnatal luteinizing hormone, but not follicle-stimulating hormone responsiveness, to estradiol negative feedback in the female. Endocrinology, 146, 4281-4291.

Seminara, S.B., Messager, S., Chatzidaki, E.E., Thresher, R.R., Acierno, J.S Jr, Shagoury, J.K., Bo-Abbas, Y., Kuohung, W. et al. (2003) The GPR54 gene as a regulator of puberty. New Engl. J. Med., 349, 1614-1627.

Sharma, T.P., Herkimer, C., West, C., Ye, W., Birch, R., Robinson, J.E., Foster, D.L. \& Padmanabhan, V. (2002) Fetal programming: prenatal androgen disrupts positive feedback actions of estradiol but does not affect timing of puberty in female sheep. Biol. Reprod., 66, 924-933.

Sheppard, K.M., Padmanabhan, V., Coolen, L.M. \& Lehman, M.N. (2011) Prenatal programming by testosterone of hypothalamic metabolic control neurones in the ewe. J. Neuroendocrinol., 23, 401-411. 
Sirmans, S.M. \& Pate, K.A. (2014) Epidemiology, diagnosis, and management of polycystic ovary syndrome. Clin. Epidemiol., 6, 1-13.

Smith, J.T., Li, Q., Yap, K.S., Shahab, M., Roseweir, A.K., Millar, R.P. \& Clarke, I.J. (2011) Kisspeptin is essential for the full preovulatory LH surge and stimulates GnRH release from the isolated ovine median eminence. Endocrinology, 152, 1001-1012.

Steckler, T., Manikkam, M., Inskeep, E.K. \& Padmanabhan, V. (2007) Developmental programming: follicular persistence in prenatal testosterone-treated sheep is not programmed by androgenic actions of testosterone. Endocrinology, 148, 3532-3540.

Steckler, T.L., Herkimer, C., Dumesic, D.A. \& Padmanabhan, V. (2009) Developmental programming: excess weight gain amplifies the effects of prenatal testosterone excess on reproductive cyclicity - implication to PCOS. Endocrinology, 150, 1456-1465.

Sullivan, S.D. \& Moenter, S.M. (2004) y-Aminobutyric acid neurons integrate and rapidly transmit permissive and inhibitory metabolic cues to gonadotropin-releasing hormone neurons. Endocrinology, 145, 1194-1202.

Unsworth, W.P., Taylor, J.A. \& Robinson, J.E. (2005) Prenatal programming of reproductive neuroendocrine function: the effect of prenatal androgens on the development of estrogen positive feedback and ovarian cycles in the ewe. Biol. Reprod., 72, 619-627.

Veiga-Lopez, A., Ye, W., Phillips, D.J., Herkimer, C., Knight, P.G. \& Padmanabhan, V. (2008) Developmental programming: deficits in reproductive hormone dynamics and ovulatory outcomes in prenatal, testosterone-treated sheep. Biol. Reprod., 78, 636-647.
Veiga-Lopez, A., Astapova, O.I., Aizenberg, E.F., Lee, J.S. \& Padmanabhan, V. (2009) Developmental programming: contribution of prenatal androgen and estrogen to estradiol feedback systems and periovulatory hormonal dynamics in sheep. Biol. Reprod., 80, 718-725.

Veiga-Lopez, A., Lee, J.S. \& Padmanabhan, V. (2010) Developmental programming: insulin sensitizer treatment improves reproductive function in prenatal testosterone-treated female sheep. Endocrinology, 151, 40074017.

Veiga-Lopez, A., Steckler, T.L., Abbott, D.H., Welch, K.B., MohanKumar, P.S., Phillips, D.J., Refsal, K. \& Padmanabhan, V. (2011) Developmental programming: impact of excess prenatal testosterone on intrauterine fetal endocrine milieu and growth in sheep. Biol. Reprod., 84, 87-96.

Vulliémoz, N.R., Xiao, E., Xia-Zhang, L., Wardlaw, S.L. \& Ferin, M. (2005) Central infusion of agouti-related peptide suppresses pulsatile luteinizing hormone release in the ovariectomized rhesus monkey. Endocrinology, 146, 784-789.

Wakabayashi, Y., Nakada, T., Murata, K., Ohkura, S., Mogi, K., Navarro, V.M., Clifton, D.K., Mori, Y. et al. (2010) Neurokinin B and dynorphin $\mathrm{A}$ in kisspeptin neurons of the arcuate nucleus participate in generation of periodic oscillation of neural activity driving pulsatile gonadotropin-releasing hormone secretion in the goat. J. Neurosci., 30, 3124 3132

Wood, R.I. \& Foster, D.L. (1998) Sexual differentiation of reproductive neuroendocrine function in sheep. Rev. Reprod., 3, 130-140. 